\title{
SIKAP SISWA PADA PEMBELAJARAN PRAKTEK SISTEM BAHAN BAKAR BENSIN DENGAN HASIL BELAJAR
}

\author{
Hilman Parid ${ }^{1}$, Inu H. Kusumah' ${ }^{2}$, Tatang Permana ${ }^{3}$ \\ Departemen Pendidikan Teknik Mesin \\ Universitas Pendidikan Indonesia \\ Jl. Dr. Setiabudhi No. 207 Bandung 40154 \\ parid.hilman.tm@yahoo.com
}

\begin{abstract}
ABSTRAK
Tujuan dari penelitian ini adalah untuk mengetahui hubungan antara sikap siswa pada pembelajaran praktek dengan hasil belajar siswa Jurusan Teknik Sepeda Motor pada mata pelajaran sistem bahan bakar bensin di SMK. Penelitian menggunakan metode korelasional. Hasil penelitian menunjukkan bahwa dari 67 siswa sebanyak 20 siswa memiliki sikap yang tergolong baik, dengan sikap belajar siswa pada pembelajaran praktek termasuk baik dan hasil belajar siswa yang baik. Korelasi antara sikap siswa pada pembelajaran praktek dengan hasil belajar siswa masing-masing berada pada kategori baik dan berasosiasi signifikan. Nilai koefisien determinasi yaitu sebesar 0,127 atau $13 \%$, artinya status sikap siswa pada pembelajaran praktek dengan hasil belajar siswa memiliki pengaruh sebesar $13 \%$, sedangkan sisanya $88 \%$ dipengaruhi oleh variabel lain.
\end{abstract}

Kata kunci : sikap, pembelajaran, bensin, bahan bakar

\section{PENDAHULUAN}

Berdasarkan salah satu tujuan SMK yang telah dikemukakan bahwa kualitas tamatan salah satunya yaitu hasil yang dicapai siswa dalam pembelajaran, Kemampuan-kemampuan yang dimiliki siswa setelah ia menerima pengalaman belajarnya (Sudjana, 2013). Harapan yang diinginkan oleh SMK Negeri 8 Bandung, siswanya mendapatkan hasil yang bagus dan menjadi tamatan yang berkualitas. Kenyataannya bahwa siswa di SMK Negeri 8 Bandung mengalami berbagai macam kesulitan untuk mencapai keberhasilan dalam prestasi belajarnya. Berdasarkan pengamatan penulis, sebanyak $44 \%$ siswa belum berhasil didalam mata pelajaran sistem bahan bakar bensin, hasil tersebut belum mencapai hasil yang optimal. Berikut ini hasil belajar siswa kelas XI TSM di SMK negeri 8 Bandung pada mata pelajaran produktif yang bersumber dari nilai Ujian Akhir Semester (UAS) Ganjil Tahun ajaran 2013/2014.

Siswa SMK Negeri 8 Bandung sebanyak $44 \%$ pada pembelajaran praktek sistem bahan bakar bensin dinyatakan belum lulus. Hasil tersebut belum menunjukkan pencapaian hasil belajar yang maksimal. Hal tersebut diindikasi bahwa adanya pengaruh dari sikap belajar siswa pada pembelajaran praktek sistem bahan bakar bensin. Siswa pada saat melaksanakan

\footnotetext{
${ }^{1}$ Mahasiswa Departemen Pendidikan Teknik Mesin FPTK UPI

${ }^{2}$ Dosen Departemen Pendidikan Teknik Mesin FPTK UPI

${ }^{3}$ Dosen Departemen Pendidikan Teknik Mesin FPTK UPI
} 
pembelajaran praktek sistem bahan bakar bensin yang kurang serius (Benny, 2009). Contohnya siswa bercanda pada saat praktek, siswa melakukan aktifitas lain selain praktek. Siswa yang melakukan kegiatan lain pada saat praktek ketika diperingatkan oleh guru mereka tidak menurut sehingga pembelajaran terganggu. Hal ini karena ada keterkaitannya dengan sikap siswa pada pembelajaran praktek dengan hasil belajar. Tujuan penelitian ini yaitu untuk mengetahui seberapa besar sikap dan hasil belajar siswa pada pembelajaran praktek sistem bahan bakar bensin dan sejauhmana hubungan sikap siswa tersebut dengan prestasi belajar siswa.

Sikap digolongkan ke dalam dua kerangka pemikiran yang dikemukakan oleh para ahli. Sikap adalah suatu reaksi evaluasi atau reaksi perasaan. Perasaan seseorang terhadap suatu obyek adalah perasaan mendukung atau memihak (favorable) maupun perasaan tidak mendukung atau tidak memihak (unfavorable) pada obyek tersebut (Azwar, 1997). Faktorfaktor yang mempengaruhi prestasi belajar seseorang yaitu pengalaman pribadi sebagai dasar pembentukan sikap, pengalaman pribadi haruslah meninggalkan kesan yang kuat. Pengaruh orang lain yang dianggap penting, yang cenderung untuk memiliki sikap yang konformis atau searah dengan sikap orang yang dianggap penting. Pengaruh pembudayaan, tanpa disadari kebudayaan telah menanamkan garis pengarah sikap kita terhadap berbagai masalah. Media massa, pemberitaan surat kabar maupun radio atau media komunikasi lainnya. Lembaga pendidikan dan lembaga agama, konsep moral dan ajaran dari lembaga pendidikan dan lembaga agama sangat menentukan sistem kepercayaan. Faktor emosional, kadang kala, suatu bentuk sikap merupakan pernyataan yang didasari emosi yang berfungsi sebagai semacam penyaluran frustasi atau pengalihan bentuk mekanisme pertahanan ego (Riyanto, 2010).

Sikap memiliki karakteristik, yaitu sikap mempunyai arah, artinya sikap terpilih pada dua arah kesetujuan yaitu apakah setuju atau tidak, apakah mendukung atau tidak mendukung. Sikap mempunyai intensitas, artinya kedalaman atau kekuatan sikap terhadap sesuatu belum tentu sama walaupun aranya mungkin tidak berbeda. Sikap mempunyai keluasan, artinya kesetujuan atau ketidak setujuan terhadap suatu obyek sikap dapat mengenai hanya aspek yang sedikit dan sangat spesifik akan tetapi dapat pula mencakup banyak sekali aspek yang ada pada obyek sikap. Sikap mempunyai konsistensi, maksudnya adalah kesesuaian antara pernyataan sikap yang dikemukakan dengan responya terhadap obyek sikap termaksud. Sikap mempunyai spontanitas, yaitu menyangkut sejauhmana kesiapan individu untuk menyatakan sikapnya secara spontan (Saripudin,1995). 
Hasil belajar merupakan indikator dari perubahan dan perkembangan perilaku dalam teori kognitif (penalaran), apektif (penghayatan) dan konatif (keterampilan). Perubahan dan perkembangan ini mempunyai arah positif atau negatif dan kualifikasinya akan terbagi-bagi seperti tinggi, sedang, rendah, berhasil atau tidak berhasil dan lulus atau tidak lulus (Muhibbin, 2009). Hasil belajar yang dicapai oleh individu merupakan hasil pengaruh individu itu sendiri dalam interaksi dengan lingkungannya (Surya, 1992). Hasil belajar adalah perubahan yang mengakibatkan manusia berubah dalam sikap dan tingkah lakunya. Sikap sangat mempengaruhi pembelajaran. Sikap siswa pada pembelajaran praktek sistem bahan bakar merupakan keyakinan seorang siswa mengenai pembelajaran praktek, yang disertai adanya perasaan tertentu, dan memberikan rangsangan kepada siswa tersebut untuk membuat respons atau berperilaku dalam cara tertentu sesuai pilihannya. Sikap siswa pada pembelajaran praktek sistem bahan bakar mempengaruhi tindakan siswa tersebut dalam menentukan jenis pembelajaran praktek.

\section{METODE PENELITIAN}

Metode yang digunakan adalah metode korelasional Objek dalam penelitian ini adalah sikap siswa pada pembelajaran praktek pada mata pelajaran sistem bahan bakar bensin. Adapun variabel dalam penelitian ini yaitu sikap siswa pada pembelajaran praktek dan hasil belajar siswa. Jumlah populasi dalam penelitian ini sebanyak 67 siswa. Pengumpulan data yang digunakan dalam penelitian ini adalah angket dan studi dokumentasi. Data yang terkumpul selanjutnya diuji validitas dan realibilitasnya. Data dalam bentuk ordinal diubah ke dalam bentuk interval dengan menggunakan Methods of Successive Interval (MSI).

\section{HASIL PENELITIAN}

Hasil yang diperoleh dari penyebaran angket untuk variabel sikap siswa (Tabel 1) pada pembelajaran praktek yang terdiri dari 36 item.

Tabel 1. Sikap siswa pada pembelajaran praktek sistem bahan bakar bensin

\begin{tabular}{cccc}
\hline Rentang skor & Kategori & Frekuensi & Persentase(\%) \\
\hline $27-33$ & Sangat Buruk & 4 & $5,97 \%$ \\
$34-40$ & Buruk & 9 & $13,44 \%$ \\
$41-47$ & Kurang Baik & 14 & $20,9 \%$ \\
$48-54$ & Cukup Baik & 13 & $19,40 \%$ \\
$55-61$ & Baik & 20 & $29,85 \%$ \\
$62-68$ & Sangat Baik & 7 & $10,44 \%$ \\
& Jumlah & 67 & $100 \%$ \\
\hline
\end{tabular}


Skor ideal rata-rata sikap siswa pada pembelajaran praktek yaitu sebesar 50. Data ini tergolong ke dalam kategori cukup baik. Ada 20 siswa memiliki sikap yang tergolong baik, pada pembelajaran praktek. Hal tersebut menunjukkan bahwa mayoritas siswa kelas XI TSM di SMK Negeri 8 Bandung memiliki sikap yang positif pada pembelajaran praktek sistem bahan bakar bensin.

Adapun untuk mengetahui mengenai hasil belajar pada pembelajaran praktek sistem bahan bakar bensin, peneliti menggunakan data nilai akhir siswa pada pembelajaran praktek sistem bahan bakar bensin yang terdiri dari 36 item pernyataan kepada 67 siswa SMK Negeri 8 Bandung. Hasil belajar siswa (Tabel 2) pada pembelajaran praktek sistem bahan bakar bensin pada siswa kelas XI TSM SMK Negeri 8 Bandung.

Tabel 2. Data hasil belajar siswa pada pembelajaran praktek

\begin{tabular}{cccc}
\hline Rentang skor & Kategori & Frekuensi & Persentase(\%) \\
\hline $27-33$ & Sangat Buruk & 1 & $1,49 \%$ \\
$34-40$ & Buruk & 1 & $1,49 \%$ \\
$41-47$ & Kurang Baik & 14 & $20,9 \%$ \\
$48-54$ & Cukup Baik & 16 & $23,88 \%$ \\
$55-61$ & Baik & 18 & $26,86 \%$ \\
$62-68$ & Sangat Baik & 17 & $25,38 \%$ \\
& Jumlah & 67 & $100 \%$ \\
\hline
\end{tabular}

Skor ideal rata-rata hasil belajar siswa pada pembelajaran praktek yaitu sebesar 55,22. Data ini tergolong ke dalam kategori baik Ada 18 siswa tergolong kedalam kategori baik. Hal tersebut menunjukkan bahwa mayoritas siswa kelas XI TSM di SMK Negeri 8 Bandung memiliki hasil belajar yang bagus pada pembelajaran praktek sistem bahan bakar bensin. Uji koefisien korelasi dilakukan untuk mengukur hubungan antar variabel telah di hitung dan di tingkas (Tabel 3).

Tabel 3. Korelasi

\begin{tabular}{ccc}
\hline & Sikap $(\mathrm{X})$ & Hasil (Y) \\
\hline Sikap (X) & 1 & 0,356 \\
Hasil (Y) & 0,356 & 1 \\
\hline
\end{tabular}

Nilai koefisien korelasi pearson antara variabel sikap siswa pada pembelajaran praktek (X) dengan variabel hasil belajar siswa pada pembelajaran praktek (Y) sebesar 0,356. Apabila di interpretasi hasil korelasi tersebut berada dalam kategori rendah dengan arah hubungan yang linear positif. 
Persamaan regresi didasarkan pada hasil perhitungan diperoleh hasil analisis yaitu 0,003. Diketahui bahwa nilai sigifikan 0,003 < 0,05. Hasil tersebut menunjukkan bahwa Ho ditolak dan Ha diterima, sehingga dapat diartikan koefisien regresi signifikan atau sikap siswa pada pembelajaran praktek benar-benar berhubungan dengan hasil belajar siswa pada pembelajaran praktek.

Uji signifikansi korelasi dapat dilakukan dengan uji t, ini dilakukan untuk mengetahui korelasi dari variabel bebas terhadap variabel terikat. Hasil pengujian hipotesis yaitu $t_{\text {hitung }}$ lebih besar dari $t_{\text {tabel}}$. Diketahui bahwa variabel sikap siswa pada pembelajaran praktek $(\mathrm{X})$ memiliki $t_{\text {hitung }}>t_{\text {tabel }}(7,614>1,67)$. Hasil tersebut dapat diartikan yakni menolak Ho dan menerima Ha. Ini berarti bahwa sikap siswa pada pembelajaran praktek (X) berhubungan secara signifikan pada hasil belajar siswa pada pembelajaran praktek (Y).

Berdasarkan hasil perhitungan koefisien determinasi $\left(\mathrm{R}^{2}\right)$ yaitu sebesar 0,127 atau $13 \%$, hasil tersebut menunjukkan kedalam kategori rendah. Ini artinya status sikap siswa pada pembelajaran praktek dengan hasil belajar siswa memiliki pengaruh sebesar 13\%, sedangkan sisanya $88 \%$ dipengaruhi oleh variabel lain yang di dalam penelitian ini tidak diteliti.

\section{PEMBAHASAN}

Hasil yang diperoleh dari penelitian menunjukkan bahwa sikap siswa pada pembelajaran praktek pembelajaran sistem bahan bakar bensin di kalangan siswa kelas kelas XI TSM SMK Negeri 8 Bandung, dari 67 siswa didapat hasil sebanyak 4 siswa $(5,97 \%)$ termasuk kedalam kategori yang memiliki sikap sangat buruk, 9 siswa $(13,44 \%)$ termasuk kedalam kategori yang memiliki sikap buruk, 14 siswa $(20,9 \%)$ termasuk kedalam kategori siswa yang memiliki sikap kurang baik. 13 siswa $(19,40 \%)$ termasuk kedalam kategori siswa yang memiliki sikap cukup baik, 20 siswa $(29,85 \%)$ termasuk kedalam kategori siswa yang memiliki sikap baik, dan 7 siswa $(10,44 \%)$ termasuk kedalam kategori siswa yang memiliki sikap cukup sangat baik, jika dilihat dari rata-rata skor ideal yaitu sebesar nilai tersebut termasuk kedalam kategori baik. Data tersebut merupakan temuan yang menunjukkan sebagai gambaran atau tingkat sikap siswa pada pembelajaran praktek di kalangan siswa kelas XI TSM SMK Negeri 8 Bandung itu baik.

Data diatas menunjukkan bahwa tingkat sikap siswa pada pembelajaran praktek sistem bahan bakar tergolong kedalam kategori baik, sikap siswa yang baik tersebut muncul tidak dibawa sejak lahir melainkan terbentuk karena proses pertumbuhan dan perkembangan siswa, 
maka dari itu salah satu yang membuat sikap siswa menjadi bertumbuh dan berkembang yaitu mengikuti pembelajaran di Sekolah.

Hasil yang diperoleh dari penelitian menunjukkan bahwa sikap siswa pada pembelajaran praktek pembelajaran sistem bahan bakar bensin di kalangan siswa kelas kelas XI TSM SMK Negeri 8 Bandung, dari 67 siswa didapat hasil sebanyak 1 siswa $(1,49 \%)$ termasuk kedalam kategori yang memiliki sikap sangat buruk, 1 siswa $(1,49 \%)$ termasuk kategori yang memiliki sikap buruk, 14 siswa $(20,9 \%)$ termasuk kategori siswa yang memiliki sikap kurang baik. 16 siswa $(23,88 \%)$ termasuk kategori siswa yang memiliki sikap cukup baik, 18 siswa $(26,86 \%)$ termasuk kategori siswa yang memiliki sikap baik, dan 17 siswa $(25,38 \%)$ termasuk kategori siswa yang memiliki sikap cukup sangat baik. Jika dilihat dari rata-rata skor ideal yaitu sebesar nilai tersebut, maka termasuk ke dalam kategori baik. Data tersebut merupakan temuan yang menunjukkan sebagai gambaran atau tingkat sikap siswa pada pembelajaran praktek di kalangan siswa kelas XI TSM SMK Negeri 8 Bandung itu baik.

Data diatas menunjukkan bahwa tingkat sikap siswa pada pembelajaran praktek sistem bahan bakar tergolong kategori baik, sikap siswa yang baik tersebut muncul dengan sendirinya melainkan terbentuk karena proses pertumbuhan dan perkembangan siswa. Belajar dilakukan untuk mengusahakan adanya perubahan perilaku pada individu seseorang. Perubahan perilaku itu merupakan perolehan yang menjadi hasil belajar. Hasil belajar adalah perubahan yang mengakibatkan manusia berubah dalam sikap dan tingkah lakunya (Purwanto, 2013). Prinsipnya hasil belajar itu dapat kita ketahui bahwa perubahan perilaku itu merupakan perolehan yang menjadi hasil belajar.

Hasil penelitian, diketahui bahwa sikap siswa pada pembelajaran praktek memiliki nilai regresi sebesar 0,31 , nilai korelasi Hasil belajar pada pembelajaran praktek sebesar 0,356 , dan memiliki nilai $\mathrm{t}_{\text {hitung }}>\mathrm{t}_{\text {tabel }}(7,614>1,67)$, sehingga dapat diartikan menolak Ho dan menerima Ha. Berdasarkan temuan hasil penelitian menunjukkan bahwa sikap siswa pada pembelajaran praktek sistem bahan bakar bensin (X) memiliki hubungan positif dan signifikan dengan hasil belajar siswa pada pembelajaran praktek sistem bahan bakar bensin (Y), dan diketahui bahwa nilai $\mathrm{R}^{2}$ sebesar 0,127 atau $13 \%$. Angka tersebut menunjukkan bahwa besarnya hubungan variabel sikap siswa pada pembelajaran praktek sistem bahan bakar bensin $(\mathrm{X})$ dengan variabel hasil belajar siswa pada pembelajaran praktek sistem bahan bakar bensin (Y) sebesar 13\%, sedangkan sisanya 88\% dipengaruhi oleh variabel lain yang tidak dianalisis dalam model. 
Sikap merupakan kecenderungan yang relatif menetap untuk bereaksi dengan cara baik atau buruk terhadap orang atau barang tertentu. Sikap merupakan salah satu faktor yang dapat mempengaruhi hasil belajar seseorang di dalam proses pembelajaran. Seorang siswa yang memiliki sikap yang bagus pada saat mengikuti pembalajaran praktek sistem bahan bakar bensin. Belum tentu sikap seseorang baik mendapatkan hasil yang baik dan sikap seseorang tidak baik mendapatkan hasil yang tidak baik. Oleh karena itu, terdapat faktorfaktor lain yang dapat mempengaruhi hasil belajar seseorang untuk mendapatkan hasil yang bagus, bisa saja dari faktor lingkungan, fasilitas, dan lain-lain (Rohani, 2010).

\section{KESIMPULAN}

Kesimpulan penelitian ini adalah sikap dan hasil belajar siswa pada pembelajaran praktek sistem bahan bakar bensin di kalangan siswa kelas XI TSM SMK Negeri 8 Bandung tergolong ke dalam kategori tinggi atau positif. Artinya secara keseluruhan siswa memiliki sikap yang positif pada pembelajaran praktek sistem bahan bakar bensin. Tetapi terdapat hubungan yang rendah, namun posistif antara sikap siswa dengan hasil belajarnya.

\section{DAFTAR PUSTAKA}

Azwar, S. (1997). Sikap Manusia Teori dan Pengukurannya. Yogyakarta: Pustaka Pelajar.

Benny A.P. (2009). Model Desain Sistem Pembelajaran. Jakarta: Dian Rakyat

Muhibbin, S. (2009). Psikologi Pendidikan dengan Suatu Pendekatan Baru. Bandung: Remaja Rosdakarya.

Riyanto, Y (2010). Paradigma Baru Pembelajaran. Jakarta: Prenada Media Grup

Rohani, A (2010). Pengelolaan Pengajaran. Jakarta: Rineka Cipta

Saripudin, A. (1995). Psikologi Pendidikan. Bandung: Angkasa.

Sudjana, N. (2013). Penilaian Hasil Proses Belajar Mengajar. Bandung: Remaja Rosdakarya.

Surya, M. (1992). Psikologi Pendidikan. Bandung: Jurusan PPB UPI

Purwanto. (2013). Evaluasi Hasil Belajar. Yogyakarta: Pustaka Pelajar 